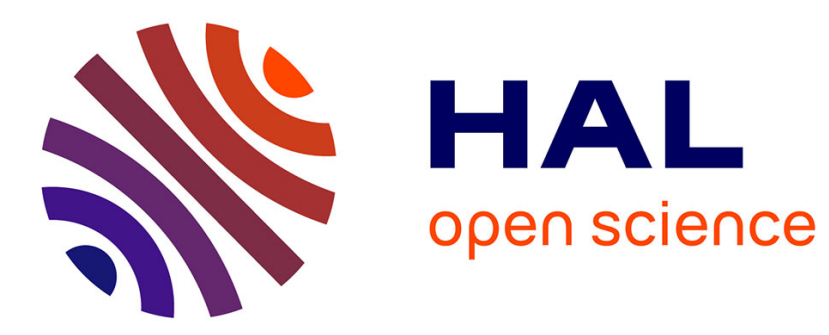

\title{
Investigation of phase equilibria in the ternary Ti-Al-Sn
}

M. Pietzka, U. Gruber, J. Schuster

\section{To cite this version:}

M. Pietzka, U. Gruber, J. Schuster. Investigation of phase equilibria in the ternary Ti-Al-Sn. Journal de Physique IV Proceedings, 1993, 03 (C7), pp.C7-473-C7-476. 10.1051/.jp4:1993776 . jpa-00252196

\section{HAL Id: jpa-00252196 https://hal.science/jpa-00252196}

Submitted on 1 Jan 1993

HAL is a multi-disciplinary open access archive for the deposit and dissemination of scientific research documents, whether they are published or not. The documents may come from teaching and research institutions in France or abroad, or from public or private research centers.
L'archive ouverte pluridisciplinaire HAL, est destinée au dépôt et à la diffusion de documents scientifiques de niveau recherche, publiés ou non, émanant des établissements d'enseignement et de recherche français ou étrangers, des laboratoires publics ou privés. 


\title{
Investigation of phase equilibria in the ternary Ti-Al-Sn
}

\author{
M. PIETZKA, U. GRUBER and J.C. SCHUSTER
}

Institut f. Physikal Chemie, Universität Wien, 1090 Wien, Austria

\begin{abstract}
Phase equilibria of the system Ti-Al-Sn at $900^{\circ} \mathrm{C}$ were investigated and are presented in form of an isothermal section. The occurrence of a ternary phase TisSnzAl having WsSi3-type structure is reported.
\end{abstract}

\section{INTRODUCTION}

The ternary system $\mathrm{Ti}-\mathrm{Al}-\mathrm{Sn}$ became of interest within the action COST 507, which aims for the thermodynamic description of multicomponent light alloys. The only reference dealing with the constitution of this system reports for the vertical section Ti3Al-Ti3Sn a complete series of solid solutions $\mathrm{Ti}(\mathrm{Al} \times \mathrm{Sn} 1-\mathrm{x})$ at temperatures below $1000^{\circ} \mathrm{C}(1)$. Since no information on equilibria with other phases were reported, a complete isothermal section was investigated and the results are presented here.

\section{EXPERIMENTAL}

Using powders of the elements (Ti,purity: $99 \%$, from Johnson Matthey, Alpha Products,FRG; Al, purity: $99.8 \%$, from Strem Chemicals,USA; and Sn purity: $99.5 \%$, from Alpha Div., Ventron Corp.,USA) 22 ternary and 4 binary alloys were prepared by arc melting the powder compacts under pure argon followed by heat treatment at $900^{\circ} \mathrm{C}$ for 140 hours. All alloys were water quenched and analysed by XRD (Guinier-Huber cameras, CuK $\alpha_{1}$ radiation). The diffraction data were handled and evaluated using the sof tware package STRUKTUR (2). 


\section{RESULTS}

\section{ISOTHERMAL SECTION AT $900^{\circ} \mathrm{C}$}

The phase field partition ( $f$ ig. 1) is characterized by the occurence of a ternary phase, TisSnzAl, and considerable solubility of aluminium in Ti6Sn5 (up to 3 at\% Al) as well as in TisSn3 (up to 18at\% Al). On the other hand, in the binary phases TiAl3, TiAl2 and TiAl no solubility of $t$ in was observed. The formation of a continous series of solid solutions between the isostructural phases Ti3Sn and Ti3Al is confirmed. The three-phase fields observed are:

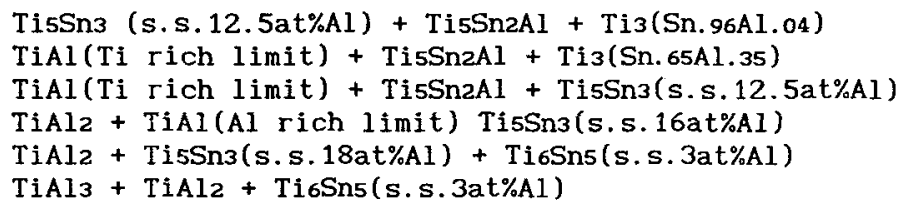

Alloys less rich in titaniun than alloys along the tie line TiAl3 + Ti6Sn5 contained liquid phase.

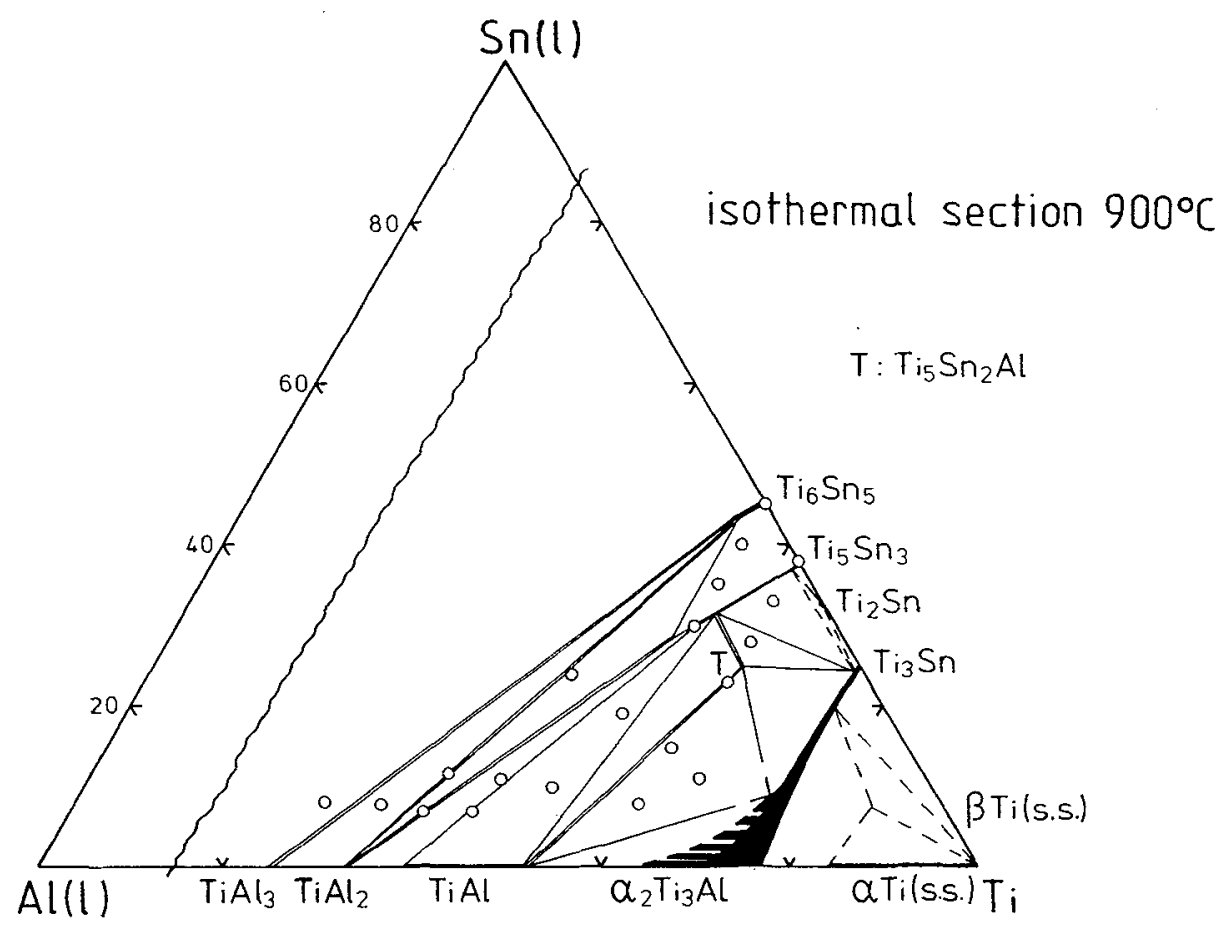

Fig. 1: Isothermal section at $900^{\circ} \mathrm{C}$ 


\section{THE TERNARY PHASE TisSnzAl}

A ternary intermetallic phase with the approximate composition TisSn2Al is observed for the first time. This phase coexist with TiAl(s.s.Sn), TisSn3(s.s.Al) and Ti3Sn(s.s.Al). The x-ray diffraction powder pattern (tab.1) is indexed based on a body centered tetragonal unit cell with $a=1.0549(2) \mathrm{nm}$ and $\mathrm{c}=0.5242(2) \mathrm{nm}$ in the alloy Ti62Sna3Al15, which was almost homogeneous containing only traces of TisSn3(s.s.Al) and TiAl. The existence of a substantial homogeneity range is indicated by the variation of the lattice parameters with the composition of the alloy, e.g. in Ti62Snz8Al10 $a=1.0564 \mathrm{~nm}, c=0.5264 \mathrm{~nm}$ (coexisting with TisSn3(s.s.Al) and Ti3Sn(s.s.Al). The intensities of the diffraction peaks can be described satisfactorily by a W5Si3 type related crystal structure with spacegroup $14 / \mathrm{mcm}$ and $16 \mathrm{Ti}(1)$ in position (16k), $4 \mathrm{Ti}(2)$ in position (4b),8 $\mathrm{Sn}$ in position ( $8 \mathrm{~h}$ ) and $4 \mathrm{Al}$ in position (4a) $(\mathrm{tab}, 1)$.

Tab. 1 X-ray Powder Diffractogram of TisSn2Al in Ti62Sn23Al15

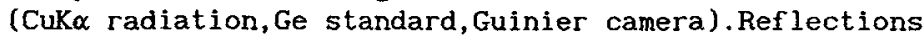
having a calculated intensity $<5$ are omitted.

\begin{tabular}{|c|c|c|c|c|c|c|c|}
\hline $\mathrm{H}$ & $\mathrm{K}$ & $\mathrm{L}$ & $\sin ^{2} \theta_{o b s}$ & $\sin ^{2} \theta_{\operatorname{cal} c}$ & Int. obs & Int. cal & \\
\hline 1 & 1 & 0 & 0.0107 & 0.0107 & $\mathbf{w}$ & 8 & \\
\hline 2 & 0 & 0 & 0.0213 & 0.0213 & $\mathbf{w}$ & 6 & \\
\hline 2 & 1 & 1 & 0.0483 & 0.0482 & $\mathbf{s}$ & 66 & \\
\hline 0 & 0 & 2 & 0.0862 & 0.0864 & $\mathrm{~m}$ & 28 & \\
\hline 3 & 2 & 1 & 0.0909 & 0.0909 & $\mathrm{~m}$ & 28 & \\
\hline 3 & 3 & 0 & 0.0959 & 0.0960 & m & 30 & \\
\hline 4 & 2 & 0 & 0.1066 & 0.1066 & $\mathrm{~ms}$ & 24 & coinc. TisSn 3 \\
\hline \multirow[t]{2}{*}{2} & 0 & 2 & 0.1078 & 0.1077 & $\mathrm{~m}$ & 27 & \\
\hline & & & 0.1095 & & VW & & TiAl \\
\hline \multirow[t]{2}{*}{4} & 1 & 1 & 0.1123 & 0.1122 & vs & 100 & \\
\hline & & & 0.1177 & & W & & TisSn3 \\
\hline 2 & 2 & 2 & 0.1290 & 0.1290 & $\mathbf{W}$ & 8 & \\
\hline 3 & 1 & 2 & 0.1398 & 0.1397 & VW & 7 & \\
\hline 4 & 0 & 2 & 0.1720 & 0.1717 & W & 17 & \\
\hline 5 & 2 & $\overline{1}$ & 0.1763 & 0.1762 & $w$ & 21 & \\
\hline 5 & 3 & 0 & 0.1815 & 0.1813 & VW & 5 & \\
\hline 3 & 3 & 2 & 0.1827 & 0.1823 & $\mathbf{W}$ & 18 & \\
\hline 6 & 0 & 0 & & 0.1919 & & 8 & \\
\hline 4 & 2 & 2 & 0.1925 & 0.1930 & $\mathbf{V W}$ & 1 & \\
\hline 2 & 1 & 3 & 0.2208 & 0.2210 & VW & 9 & \\
\hline 7 & 1 & 0 & & 0.2666 & & 8 & \\
\hline 5 & 3 & 2 & 0.2670 & 0.2676 & W & 9 & \\
\hline 4 & 1 & 3 & 0.2851 & 0.2849 & $\mathrm{~m}$ & 27 & \\
\hline 6 & 2 & 2 & 0.2997 & 0.2996 & VW & 3 & \\
\hline 7 & 2 & 1 & 0.3042 & 0.3041 & $\mathrm{VW}$ & 3 & \\
\hline 7 & 3 & 0 & 0.3089 & 0.3092 & VW & 7 & \\
\hline 0 & 0 & 4 & 0.3457 & 0.3456 & $\mathrm{VW}$ & 8 & \\
\hline 5 & 2 & 3 & 0.3492 & 0.3489 & $\mathrm{VW}$ & 9 & \\
\hline 7 & 1 & 2 & 0.3527 & 0.3529 & n.d. & 11 & coinc. Ge \\
\hline 6 & 4 & 2 & 0.3635 & 0.3634 & w & 18 & \\
\hline 8 & 1 & 1 & 0.3684 & 0.3683 & $\mathbf{w}$ & 19 & \\
\hline 6 & 6 & 0 & 0.3841 & 0.3840 & vw & 4 & \\
\hline 7 & 3 & 2 & 0.3955 & 0.3954 & VW & 15 & \\
\hline
\end{tabular}




\section{REFERENCES CITED}

[1] I. I. Kornilov and T.G.Nartova, Doklady Akad.Nauk SSSR, 140 (1961) 829

[2] W. Wacha, Thesis, Vienna Institute of Technology, 1989

\section{ACKNOWLEDGEMENT}

This research was funded in part by the Austrian Science Foundation (project P7853 PHY). 